doi: $10.21464 /$ fi36316

\section{Friedrich Nietzsche}

\section{Ljudsko, odviše ljudsko}

\section{Knjiga za slobodne duhove: svezak drugi}

\section{Demetra, Zagreb 2013.}

Ljudsko odviše ljudsko - knjiga za slobodne duhove, epohalno dvosveščano filozofsko djelo Friedricha Nietzschea, u nas biva objavljeno pod okriljem izdavačke kuće Demetra u Zagrebu, svibnja 2013., uz sjajan prijevod Berislava Podruga. U usporedbi s prvim sveskom svojeg veličanstvenog spisa, čiji recenzivni prikaz bijaše objavljen u broju 140 Filozofskih istraživanja, a kojeg je Nietzsche sročio u pet glavnih dijelova, drugi piše kroz dva glavna dijela: »Mnijenja i razne izreke« (408 fragmenata) $\mathrm{i} »$ Putnik i njegova sjena« (350 fragmenata). Čini se da je fragmentarna kauzalnost drugog sveska zahtjevnija za praćenje, nego ona prvog sveska s obzirom da odiše (naizgled) frenetično šarolikim rasponom tema i motiva što kroz njih vriju te čiji misaoni prijelazi i refreni bivaju teško ulovljivi i najplemenitijim filozofskim ušima. Međutim, nipošto se ne bi moglo kazati da određena međufragmentarna kauzalnost (koja i jest stilska logosna karakteristika filozofskog, znanstveno-umjetničkog genija kakav je Nietzsche), ne postoji. Dotična dva poglavlja prvotno bijahu objavljeni zasebno, kao nastavci i prilozi prvog sveska, a ujedno i kao, iskazano Nietzscheovim riječima,

»Nastavak i udvostručenje jedne duhovne kure, naime antiromantičkog sebeliječenja, kakvo mi je moj još uvijek zdrav instinkt bio sam iznašao i sam propisao protiv privremenog oboljenja od najopasnijeg oblika romantike«.

Navedene retke piše imajući pri umu ponajprije vlastiti raskol s Richardom Wagnerom i antiromantičku svjetlosnu (aletejsku) katarzu kojom je pritom bivao blagoslovljen. Nakon šest godina, kako sam kaže "prizdravljanja«, spise objavljuje objedinjene, kao drugi svezak Ljudskog, odviše ljudskog, nadajući se da će tako zajedno objavljeni, i zajedno razmotreni, polučiti nauk o zdravlju još snažnije i jasnije, a navedeni nauk o zdravlju Nietzsche preporuča duhovnijim naravima nadolazećeg razdoblja za disciplinu i izobrazbu volje, te kroz svih osam predgovornih fragmenata upućuje čitatelja na vlastito razrješavanje s prošlošću nakon čega, smatra, nastupa slobodonosna katarza duha.

U prvom predgovornom fragmentu Nietzsche piše da treba zboriti samo ono o čemu se ne smije šutjeti, te samo o onome što se prevladalo jer je sve drugo naklapanje, literatura, nedostatak zapta i strogog odgoja. Također, navodi i kako svi njegovi spisi govore o onome iza njega, pritom misleći na činjenicu da mu je uvijek bilo potrebno vremena, prizdravljanja, udaljenosti i distance prije nego što se u njemu probudila želja da se doživljeno iznese na vidjelo. Na kraju četvrtog predgovornog fragmenta stoji da su naša rasterećenja ono zbog čega najviše ispaštamo i želimo li ponovno ozdraviti nemamo izbora - moramo se opteretiti teže no što smo ikada bili opterećeni, a izdvojio bih i citat iz šestog predgovornog fragmenta $u$ kojem Nietzsche kazuje kome posvećuje ovaj spis, citiram

»Prije svega pak vama koji to najteže podnosite, vi rijetki, najugroženiji, najduhovniji, najodvažniji, vi koji morate biti savjest moderne duše, te koji kao takvi morate imati njeno znanje, vi u kojima se sabire ono što samo danas može biti od bolesti, otrova i opasnosti, - čija sudbina hoće to da morate biti bolesniji od bilo kojeg pojedinca jer vi niste 'tek samo pojedinci', čija je utjeha znati put k jednom novom zdravlju, ah! te njime ići i putiti se , naime zdravlju sutrašnjice i preksutrašnjice, vi predodređeni, pobjedonosni, vi nadvladatelji vremena, vi najzdraviji i najsnažniji, vi dobri Europljani!« (str. 7)

»Razna mnijenja i izreke«, prvi dio drugog sveska, tematski se podudara s naslovom poglavlja uzmemo li u obzir činjenicu da se kroz njega provlače uistinu raznovrsne ideje kroz oštroumna Nietzscheova opažanja upisana $u$ 408 ponajčešće kratkih dvo- ili trorečeničnih fragmenata, a motivi kojima su prožeti sežu od istočnog grijeha filozofa, skepse kršćana, pa do starih Grka, pustinje znanosti, knjiga i kritičara, ratnog lukavstva nametljiva čovjeka, neslobodi volje, duha žena, mudraca koji se pravi da je budala, genija itd. S obzirom na osebujnu kvantitetu fragmenata, na prvi pogled biva zamjetljivo kako je gotovo nemoguće u nekoliko stranica ogresti tkivo svakog pojedinog fragmenta i važne misli ovog poglavlja, te stoga nastojim iznijeti one, po mome sudu, krucijalne.

Krenuo bih 7. fragmentom naslova »Neprijateljstvo spram svjetla« u kojem Nietzsche razmatra ljudsku fobiju spram svjetlosti istine tvrdeći da ljudi u dubini svoje duše mrze istinu zbog njezine određenosti:

» Je li razlog tome što oni svi zajedno potajice strepe da će jednoga dana u njih biti prejako upereno svjetlo istine? Oni hoće nešto značiti, pa se zbog toga ne smije točno znati što oni doista jesu? Ili je posrijedi samo strah od presjajnog svjetla, na kojeg njihove zamračive, lako zasljepljujuće šišmiševe duše nisu svikle, tako da ga i one moraju mrziti?« (str. 13) 
Smatram kako oba odgovora nose dijelić istine, ali čini mi se kako je apriorna fobija što mori ljudski rod ona spram autoistine koja nakon nekog vremena prelazi u mržnju spram svakog oblika svjetlosne istine, za čiju svjetlosnost potom njihovi mahom polutanski umovi gaje isključivo otpor i popratno odbijanje svakog vida razotkrivanja, koje s vremenom prelaze čak i u prijezir. Očiti dokaz navedenog ukazuje nam se i u današnje vrijeme, za kojeg prisustvujemo festivalu općeg mazanja očiju i svekolike lobotomije. 18. fragment - »Tri vrste mislioca« - nudi metaforu kojom Nietzsche iznosi misao kako postoje bujajući, tekući i kapajući izvori mineralne vode, a u skladu s time postoje i tri vrste mislioca. Laik ih procjenjuje prema masi vode, a znalac prema sadržaju vode, dakle prema onome što u njima upravo nije voda. Naglašavam neminovnu potrebu ljudskog roda za znanstvenim (ponajprije filozofijskim) znalcima koji su sposobni ukazati čovječanstvu na kukolj koji se prodaje pod bitak raznim marketinškim trikovima i smicalicama, kao i zabludjelim obrazovnim smjerovima. Svjetlosni motiv, sličan onom iz sedmog fragmenta nalazimo i u 61. fragmentu naslova »Vidjeti svoju svjetlost kako sja« u kojem stoji:

»U zamračenim stanjima muke, bolesti i krivnje, sa zadovoljstvom primjećujemo to ako druge još prosvjetljujemo, dok oni na nama zamjećuju svijetl mjesečev kolut. Tim zaobilaznim putem mi sudjelujemo u našoj vlastitoj sposobnosti rasvjetljavanja.« (str. 31)

Nietzsche gaji istančan osjećaj za svjetlonoštvo, za koji ističem da bi nužno trebao predstavljati paradigmu svakog pojedinog obrazovanja, međutim, u današnje je opskurantsko doba sve prisutniji trend anti-aletejski nastrojenog zamračujućeg kvazi-obrazovanja projiciranog ponajprije masovnim medijima koji preuzimaju ulogu apriornog oblikovatelja ljudskog znanja, dok po svijetu djeluje nebrojeno mnogo ministarstava »obrazovanja« pojedinih država podložnih kapitalističkoj zaglupljujućoj mašineriji. 92. fragment »Navodni kršćani, a ne kršćani« ukazuje na paradoksalnost kršćanskog zrenja te pritom Nietzsche kršćanima poručuje:

»Želio bih da naučite barem kršćanske manire, budući da vam toliko nedostaje finoće i pristojnosti kršćanskog srca.« (str. 39)

109. fragment naslova »Živjeti bez umjetnosti i vina« krije jednu od ljepših metafora Nietzscheova opusa upućenu umjetnosti i njezinu alkemijskom kreativnom karakteru, citiram:

»S umjetničkim djelima je kao s vinom: još je bolje ukoliko se ni jedno ni drugo ne potrebuje, ukoliko se drži vode a vodu iz unutrašnje vatre, unutrašnje slatkoće duše, uvijek iznova samim sobom pretvara u vino.« (str. 47)
Odista sjajno konstruirana i pogođena misao logosno-krečuće paradigme koja, ukoliko provođena pravilno, utoliko pojedinca odvodi u domene sebe-rađajućeg kreativnog kolosa, vođenog istinskim praxisom autonomnog uma. U 194. fragmentu »Tri mislioca nalik jednome pauku« Nietzsche iznosi zanimljivu sliku:

»U svakoj filozofijskoj sekti slijede tri mislioca jedan za drugim u sljedećem međuodnosu: prvi stvara iz sebe sok i zametak, drugi ga razvlači u niti i plete umjetničku mrežu, a treći u toj mreži vreba žrtve koje se u njoj zapletu te od filozofije pokušava živjeti.«(str. 81)

Čini se da je situacija sa suvremenom filozofijom obilježena upravo trećim korakom. Kvazi-filozofi parazitski rasprostiru mreže historije filozofije i u tom pronalaze maksimum vlastite (prividne) sebe-rađajuće kreativnosti, te od toga pribavljaju financijska sredstva za život i maglu za trovanje mladih potencijalnih filozofskih glava. Odu Grcima pronalazimo u 218. Fragmentu »Grci kao posrednici - tumači«, u kojem stoji da, kada govorimo o Grcima, mi nehotice govorimo i o onome danas i jučer jer je njihova opće poznata povijest jedno sjajno zrcalo koje uvijek konstantno zrcali nešto što se nalazi u njemu samome. Citiram

»Mi koristimo slobodu govorenja o njima kako bismo o drugima smjeli šutjeti - kako bi oni sami odsad govorili razmišljajućem čitatelju nešto na uho. Tako Grci sadašnjem čovjeku olakšavaju priopćenje mnogočega teško priopćivog i nepovjerljivog.《 (str. 87)

Pitam se kako li se je iz duha starogrčke veličajnosti izrodio tako beskrajno barbarizirani i trivijalizirani, ali i robotizirani Europljanin današnjice? 230. fragment zbori o mjeri i sredini, a kroz njega Nietzsche umuje kako je o dvije nadasve uzvišene stvari - mjeri i sredini - najbolje nikada ne govoriti. Piše da određena nekolicina ljudi poznaje njihove moći i znamenje iz misterijskih staza unutrašnjih doživljaja i obrata, te oni pritom u njima štuju nešto božansko i zaziru od glasne, oglašavajuće riječi, dok svi ostali ljudi jedva slušaju kada se o tome zbori umišljajući si da je posrijedi dosada i osrednjost, $\mathrm{s}$ izuzetkom onih »koji su jednom razabrali opominjući zvuk toga carstva, ali su si spram njega začepili uši. Spomen na to ih pak ozlovoljuje i razjaruje." Nietzsche istančano poznaje nauk starih Grka koji u promišljanju mjere otkrivahu harmoničnu fuziju suprotnosti, odnosno dijalektičkog smiraja koji upućuje na "pravilno« usmjerenu gibajuću intencionalnost. Međutim, u 365. fragmentu pak određuje prekomjernost kao ljekovito sredstvo tvrdeći da se vlastitu nadarenost može u sebi iznova pobuditi tako da se netko duže preko mjere štuje i uživa jednu oprečnu nadarenost, a prekomjernost 
je primjenjivati kao ljekovito sredstvo jedan od najistančanijih poteza u umjetnosti života. Misli li Nietzsche na odmjerenu prekomjernost kao temeljnu supstanciju dijalektičkog kolopleta?

Nadalje, izdvajam pokoji fragment predmetno usmjeren k ženama te tako u 272. fragmentu, razglabajući o duhu žena, Nietzsche tvrdi da se njihova duhovna moć najbolje posvjedočuje time što ona iz ljubavi spram jednog muškarca i njegova duha žrtvuje svoj vlastiti duh, kao i time što njoj unatoč tome u novom, njenoj naravi izvorno stranom vidokrugu, kamo način mišljenja muškarcu nju nuka, odmah naraste jedan drugi duh. U 282. stoji da »suosjećanje žena, koje je jezičavo, iznosi krevet bolesnika na javni sajam.« (str. 109), dok u 286. fragmentu piše da su žene sazdane tako da im sva istina (glede muža, glede ljubavi, društva, životnog cilja) izaziva gađenje, te tako da se one svakome, tko im otvori oko, pokušavaju osvetiti. Čini se da Nietzsche zaista pretjeruje tako oštrom generalizacijom te se pitam kakva li ga je to mega-otrovna osoba toliko snažno i trajno ubola žalcem i inspirirala na naizgled konstantno usmjeravanje kontemplativnog oka $\mathrm{k}$ apsolutu negativiteta prilikom refleksije o ženama? Interesantnu misaonu sliku nalazimo i u 397. fragmentu u kojem Nietzsche navodi da otmjena duša nije ona koja je sposobna za najviše uzmahe, nego ona koja se malko uzdiže i malko pada, ali koja uvijek obitava u slobodnijem i obasjanijem zraku i visini, a prvi dio sveska okončava 408. fragmentom s temom odlaska u Had u kojem zbori kako je i on poput Odiseja bio u podzemnom svijetu, te u kojem će često opet tamo boraviti, pritom ne žrtvujući samo ovnove kako bi mogao razgovarati s pojedinim mrtvima, nego ne štedeći ni svoju vlastitu krv. Također piše i kako mu se četiri para, kao prinositelju žrtve, nisu uskratila: Epikur i Montaigne, Goethe i Spinoza, Platon i Rousseau, Pascal i Schopenhauer, s kojima je raspravljao dugo sam putujući i čije su oči u njega uperene. Fragment završava s:

»Neka mi živući oproste ako mi upravo oni sam gdjekad izgledaju poput sjena, tako blijedi i mrzovoljni, tako nemirni i ah! tako pomamljeni za životom: dok mi se prethodno spomenuti tad čine tako živima, kao da oni sada, nakon smrti, nikada više ne mogu biti umorni od života. No, radi se o vječnoj živosti: kome je stalo do 'vječnog života' i uopće do života.«

Prvi dio zaključuje predivnim motivom vječne živosti kao vječnog svjetla koji ukazuje na razvoj, zdravlje, napredak i kretanje duha na sve ono što represaličnost religija i politika nastoje nihilizirati.

Drugi dio nazvan je »Putnik i njihova sjena«. Nietzsche otpočinje predgovornim, pomalo shizofreničnim dijalogom putnika i vlastite sjene u kojem putnik tvrdi kako voli sjenu jednako kao što voli svjetlost jer da bi bilo jasnoće govora, dobrote i postojanosti karaktera, sjena je nužna jednako kao i svjetlo. Govori joj kako oni nisu međusobno protivnici, nego da se, ispunjeni ljubavlju, drže međusobno za ruke i kad svjetlost nestane za njom se povlači i sjena. S druge pak strane, sjena mrzi isto što i putnik - noć - s obzirom da ljubi ljude jer su oni učenici svjetlosti, te se raduje svjetlu koje se nalazi u njihovim očima kad spoznavaju i otkrivaju. Dijalog završava ujednačenim stavom putnika i sjene kako se u pojedinim nazorima ipak više opaža sjenu nego li svjetlost.

Kao i u prvom dijelu, misli su kvalitativno i kvantitativno šarolike, a roje se oko motiva uma, nauka o slobodnoj volji, umjetnosti, stupnjevima morala itd. Kroz 11. fragment »Sloboda volje i izolacija factuma« Nietzsche navodi kako svako naše djelovanje i spoznavanje nije niz factuma i praznih međuprostora, nego jedan stalan tijek, no vjera u slobodu volje nespojiva je upravo s predodžbom jedne stalne, jednovrsne, nerazdijeljene i nerazdjeljive protočnosti, jer

»... ona pretpostavlja da svako pojedino djelovanje jest izolirano i nedjeljivo, ona je a t o $\mathrm{m}$ i s t i k a u oblasti htijenja i spoznavanja. Upravo onako kako netočno razumijemo karaktere, postupamo mi također i s factumima: mi govorimo o jednakim karakterima, i jednakim factumima: Ali nema ni jednog ni drugog.

U 44. fragmentu »Stupnjevi morala«, Nietzsche kazuje da je moral ponajprije sredstvo općenitog održanja zajednice te ujedno sredstvo sprečavanja njezine propasti, a motivi su mu strah i nada. Utoliko grubiji, moćniji i siroviji, ukoliko je još uvijek snažna sklonost spram onog izopačenog, jednostranog, osobnog. U 78. fragmentu tvrdi da je tek kršćanstvo naslikalo vraga na zid svijeta te da je tek kršćanstvo na svijet donijelo grijeh, citiram:

»Vjerovanje u lijek, koje je ono protiv toga ponudilo, otada je postepeno uzdrmavano do u svoje najdublje korijenje: ali još uvijek postoji vjerovanje u bolest, vjerovanje koje je ono naučavalo, propovijedalo i naokolo širilo.« (str. 189)

Dodao bih da je kršćanstvo širitelj bolesti ponajprije zbog krađe svjetlosne aletheje, koju vrši nauštrb naivnih vjernika, dok istodobno licemjerno propovijeda svjetlost božju kao orijentir. No očigledno je da ipak projicira mračnu svjetlost tupila, pritom na metaforički križ razapinjući nebrojene umne potencijale.

U 187. fragmentu narodima koji postaju izmoždeni i bijedni kao ljekovito sredstvo preporuča rat, ako oni još i dalje žele živjeti. Smatra da za sušicu naroda postoji i jedna 
brutalna kura. Sama želja za vječnim životom, jednako kao i nesposobnost umiranja, već je jedan znak staračkog obilježja osjećanja jer što se punije, intenzivnije i valjanije živi, to se je prije spremno žrtvovati svoj život za jedan jedini dobar osjećaj. Nietzsche smatra da narodu koji tako živi i osjeća, rat nije potreban. U 267. fragmentu »Nema odgajatelja« pronalazimo stav da bi čovjek kao mislitelj trebao govoriti jedino o samoodgajanju jer je odgoj mladih ljudi ili posredstvom drugoga ili jedan eksperiment izveden na nekom još neprepoznatom, ili pak jedno načelno niveliranje $s$ ciljem da se to novo biće učini primjerenim vladajućim navikama i običajima, a

»... jednoga dana, kad se već odavno, prema općem mnijenju svijeta, jest odgojen, otkriva se samoga sebe: a tad počinje zadaća mislioca, tad je vrijeme da se njega pozove u pomoć - ne kao odgajatelja, nego kao samoodgojenika koji ima iskustvo.«

O mediokritetu kao maski zbori u 175. fragmentu navodeći da je mediokritet najsretnija maska koju može nositi nadmoćan duh jer on velikoj većini ne dopušta razmišljanje o maskiranju te on ipak stavlja masku na sebe upravo zbog njih kako ih ne bi razdraživao, nerijetko čak iz sažaljenja i dobrostivosti.

U drugom djelu »Ljudskog odviše ljudskog« Nietzsche raspon tema širi na gotovo sve pore društva, ali očito je kako mu je u pregršt fragmenata glazbena umjetnost u fokusu. Pritom se dotiče slavnih Njemačkih muzičara, te iznosi da je Bachova muzika nalik božjem stvaranju svijeta iako se u njemu nalazi previše sirovog kršćanskog nazora i sirovog njemstva, te on stoji na pragu europske moderne muzike. Handel je iskren, silan, sklon i blizak onom herojskom »za kojeg je jedan narod sposoban«, ali je pri komponiranju bio krut i hladan te čak i umoran od sebe sama; u Haydnu se ujedinila genijalnost s naprosto dobrim čovjekom te on ide točno do granice koju moralnost provlači intelektu, stvarajući čistu muziku koja nema prošlosti. Beethoven otkriva svoje melodije u monotonim napjevima putujućih Talijana, ili pak u karnevalskim noćima sabirući ih poput pčele. Nietzsche piše da su mu dotični motivi preobrazujuća i blažena sjećanja iz »boljega svijeta«, slično kao što je Platon zamišljao ideje, dok se Mozart sasvim drugačije odnosi spram svojih melodija: ne nadahnjujući se slušajući muziku, nego motreći život, najuzgibaniji južnjački život jer kad nije u njoj boravio, uvijek je sanjao Italiju. Za Franza Schuberta kaže da polaže pravo da ga se nazove idealnim pjevačem i sviračem, a u 167. fragmentu »Gdje je muzika kod kuće«, stoji:

»Svoju veliku moć muzika postiže jedino među ljudima koji nisu u stanju o nečemu diskutirati, ili pak kojima to nije dopušteno. Zato su njeni promicatelji prvoga ranga vladari koji ne žele da se u njihovoj blizini mnogo kritizira, pače, da se čak niti ne misli mnogo; zatim su tu društva koja se, pod bilo kojim pritiskom ( pritiskom vlasti ili religije) moraju naviknuti na šutnju, ali društva koja traže utoliko jače čarobno sredstvo protiv dosade osjećaja (obično vječnu zaljubljenost i vječnu muziku); treće, to su čitavi narodi u kojima »društvo« uopće ne postoji, ali u kojima se utoliko više nalazi pojedinaca sklonih samotnosti, sklonih polumračnim mislima i štovanju sveg onog neizrecivog: to su prave muzičke duše. - Grci, kao narod pričljiv i sklon prepirci, zbog toga su muziku podnosili samo kao jedan dodatan prilog umjetnostima, o kojima se doista da prepirati i pripovijedati: dok se o muzici jedva da čisto misliti. Pitagorejci, oni iznimni Grci u mnogom pogledu bili su, kako glasi predaja, također veliki muzičari: isti Pitagorejci koji su izmislili petogodišnju šutnju, ali ne dijalektiku.« (str. 218)

322. fragmentom reflektira o smrti pišući kako bi sigurnim izgledom na smrt svakom životu mogla biti primiješana jedna dragocjena, miomirisna kap lakomosti »a vi čudnovate ljekarničke duše ste pak iz nje napravili jednu neprijatnu kaplju otrova, od koje čitav život biva odvratan!« (str. 280), a kao najbolji lijek za bolesnika u 325. fragmentu dubokoumno predlaže tu i tamo malo zdravlja!? U 330. oslikava svjetioništvo slobodnih umova kazivajući da kao što nam oblaci otkrivaju smjer puhanja vjetra visoko iznad nas, tako najlakši i najslobodniji duhovi svojim usmjerenjima unaprijed najavljuju vrijeme koje dolazi, a vjetar u dolini i mnijenja današnjega sajma ne znače ništa za ono što dolazi, nego jedino ono što je bilo. 332. fragmentom nastavlja zrenje o mislilaštvu, tvrdeći da su spokoj, velebnost i sunčeva svjetlost tri stvari koje obuhvaćaju sve ono što jedan mislioc želi, kao i sve što on od sebe zahtijeva: svoja uzdanja i dužnosti, svoje intelektualne i moralne zahtjeve, i to čak u dnevnom načinu života, pa još i u krajobrazu svojega obitavališta. Nietzsche iznosi kako njima odgovaraju, kao prvo, uznoseće misli, zatim umirujuće misli, te kao treće razjašnjujuće misli, a kao četvrto pak misli koje sudjeluju u sva tri navedena svojstva, u kojima se sve zemaljsko preobražava te dospijeva u uznesenje. Piše kako je to carstvo u kojem vlada veliko »Sveto Trojstvo radosti«.

Prikaz zaključujem posljednjim, 350. fragmentom naslova »Zlatna Krilatica« kojeg odlučujem citirati čitavog s obzirom na njegov sveobuhvatni zaključni karakter, ali i na njegovu metaforičku dubinu kao i nenadmašnu »slobodonosnu« snagu, koja predstavlja svojevrsnu poslanicu Sv. Nihila kakav je Nietzsche bivao u odnosu na civilizacijske okove, citiram:

»Kako bi se odlučio ponašati poput životinje, čovjeku su postavljeni mnogi okovi: i doista, on je postao blaži, duhovniji, veseliji, razboritiji od svih životi- 
nja. Međutim on još uvijek pati zbog toga što je svoje okove nosio tako dugo, što je tako dugo bio lišen čistoga zraka i slobodna kretanja: - ti su pak okovi - ponavljam to uvijek iz nova, one teške i smislom pune zabluda moralnih, religioznih, metafizičkih predočbi. Tek kad je preboljena još i bolest okova, prvi je veliki cilj u potpunosti dosegnut: naime odvajanje čovjeka od životinja. No trenutno se mi nalazimo usred svoga posla, usred skidanja okova, te nam je pritom nužno potreban krajnji oprez. Samo oplemenjenom čovjeku smije biti dana sloboda duha; jedino se njemu bliži olakšanje života te ono iscjeljuje njegove rane. Ponajprije on smije reći da živi radi radosti i radi nijednog daljeg cilja; i u svim drugim ustima bio bi opasan njegov izborni slogan: spokoj oko mene i uživanje u svim najbližim stvarima. Pri tom izbornom sloganu za pojedince on se spominje jedne stare, velike i ganutljive riječi, koja je vrijedila naprosto za sve, i koja je nad čitavim čovječanstvom ostala stajati kao jedan izborni slogan i znamen, u kojem je propalo kršćanstvo. Kako se čini, još uvijek nije vrijeme da bi s v i ljudi mogli biti i doživljavati isto što i oni pastiri, koji su nad sobom vidjeli osvjetljeno nebo te čuli onu riječ: 'Mir na zemlji i među ljudima dobra volja.' - Još uvijek je vrijeme pojedinaca.« (str. 287)

\section{Luka Janeš}

